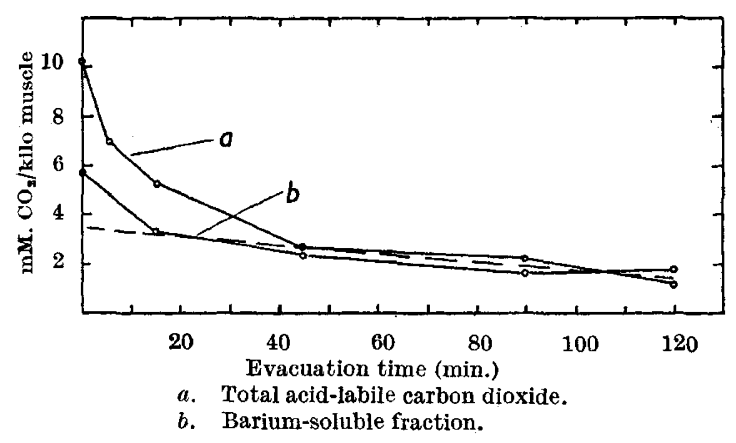

and that $[K]=5 \cdot 5$, and $[K]_{1}=157$, then since the $[\mathrm{H}]$ of serum is $10^{-7 \cdot 42}$, we obtain in turn that the value of $[\mathrm{H}]_{1}$ is $10^{-6.0}$, or the $p H=6 \cdot 0$.

In another communication Wallace and Lowry have brought evidence, as they believe, for the non. diffusibility of $\mathrm{HCO}_{3}$ ion across the muscle membrane. Such experiments are readily interpreted both from the principles outlined for electrolyte equilibria across the muscle fibre membrane and discussed at some length in the Journal of Physiology of $1941^{6}$, and the findings here described.

E. J. Conway.

P. J. Fearon.

Bfochemical Laboratory,

University College,

Dublin. Oct. 25.

'Conway, E. J., and Boyle, P. J., NAture, 144, 709 (1939).

2 Wallace, W. M., and Hastings, A. B., J. Biol. Chem., 144, 637 (1942).

Henriques, O. M., Ergeb. Physiol., 28, 625 (1929).

- Faurholt, C., J. Chem. Physiol., 21, 400 (1925).

- Roughton, F. J. W., Physiol. Rev., 15, 241 (1935).

- Boyle, P. J., and Conway, E. J., J. Physiol., 100, 1 (1941).

\section{Nitrogenous Manuring of Black Cotton Soil}

RAIN-FED cotton is the principal money erop of the black soil tracts of India ${ }^{1}$, which are often characterized by low yields and where nitrogen alone, among the three fertilizer elements nitrogen, phosphorus and potassium, has been found to be essential for increasing the yield ${ }^{2}$. Groundnut cake, ammonium sulphate and farmyard manure or compost have all given significant response, the expected increases in yield in pounds of seed cotton per acre for unit dose of nitrogen being $3 \cdot 79 \pm 0 \cdot 22,2 \cdot 24 \pm 0 \cdot 17$ and $1 \cdot 19 \pm$ $0 \cdot 17$ respectively.

Humic manures are slow-acting and do not, in consequence, compare favourably with other nitrogenous manures and fertilizers, at any rate in their immediate effect ${ }^{3}$. But the regular superiority of groundnut cake over ammonium sulphate, even on the immediate crop and, in spite of its slight but significant adverse effect on germination", was rather unexpected and warranted further exarnination. It has since been ascertained that application of groundnut cake and ammonium sulphate to the black, alkaline soil is followed by a certain amount of loss of ammonia, this loss being much more pronounced with ammonium sulphate than with the oilcake. It has been possible to measure, from time to time, the loss of gaseous ammonia in situ in field plots by a modification of the technique worked out by Subrahmanyan 5 . Thus, in plots treated with ammonium sulphate and oilcake at $80 \mathrm{lb}$. nitrogen per acre, the average loss of ammonia from random spots, over a period of 52 days, amounted to 35 and $19 \mathrm{mgm}$. respectively, the corresponding loss from untreated plots being $12 \mathrm{mgm}$. In similar experiments carried out in the laboratory, from $12 \cdot 6$ to $24 \cdot 2$ per cent of added nitrogen as ammonium sulphate could be accounted for through loss as gaseous ammoria during a period of a month, whereas, with groundnut cake, under identical conditions, the loss of ammonia ranged only from $8 \cdot 1$ to $16 \cdot 5$ per cent of the added nitrogen.

It would follow, therefore, that a given rate of application of ammonium sulphate would be less effective than its equivalent, on nitrogen basis, of groundnut cake by the extent of its increased loss of nitrogen as ammonia. An observation of interest was that loss of ammonia was considerably less where the ammonium sulphate or oilcake was drilled in furrows instead of being broadcast as is usually the case; such drilling or application at lower depths below the surface was also followed by higher increases in yield 6,7.

Loss of nitrogen from the soil through volatilization as ammonia has been noticed earlier 8,8 and would appear to be a general phenomenon with all tropical soils ; indeed, under certain conditions, most of the nitrogen added as ammonium sulphate may be lost in this form within a fortnight ${ }^{10}$. The high alkalinity ( $p \mathrm{H}$ frequently greater than 9.0) and lime status (replaceable calcium about 40 M.E.) of the black soil would doubtless favour heavy losses of ammonia from this soil, especially with high concentrations of added ammoniacal fertilizers. For this soil, therefore, it is possible that calcium nitrate may prove superior to ammonium sulphate, as has been found to be the case in the Sudan?.

\section{Institute of Plant Industry,}

\section{A. Sreenivasan.} Indore. Oct. 29.

${ }^{1}$ Bal, D. V., Empire J. Exp. Agric., 3, 261 (1935).

${ }^{2}$ Report on the results of Cotton Manurial Trials in India, Indian Central Cotton Committee, 1942.

s Sreenivasan, A., Nature, 152, 572 (1943).

- Unpublished data.

s Subrahmanyan, V., Nature, 139, 884 (1937).

- Annual Reports, Institute of Plant Industry, Indore $(1936,1937)$. ' Crowther, F., Empire J. Exp. Agric., 9, 125 (1941).

8 Hutchinson, C. M., Memoirs, Dept. Agric. India, Bacteriol. Series, 1, 41 (1910-1911).

- Sreenivasan, A., and Subrahmanyan, V., J. Agric. Sci., 25, 6 (1935). ${ }^{10}$ Subrahmanyan, V., Curr. Sci., 5, 587 (1937).

\section{Nature of the Acid in Soft Water in Relation to the Growth of Brown Trout}

As the owner of freshwater fishings in the north of Scotland, I am interested in the growth of brown trout. After making a $p \mathbf{H}$ survey of the waters in this area, it soon became evident that this $p \mathbf{H}$ reading was of very little use without knowing the factors which determined it, in Nature. Not wishing to be guilty of over-simplification or generalization, I would make it clear that these notes only refer to the natural acid waters as they occur here.

These waters are remarkable for the small quantity of minerals in solution, in many cases not exceeding 2 parts per 100,000 . They normally consist of carbonates and bicarbonates of the calcium-magnesium group. I shall refer to this as the calcium content, which is the first of the two controlling factors.

The second is the amount of carbon dioxide in solution. A neutral water, $p \mathrm{H} 7$, under the limitations 